\title{
The Relationship between Domestic Violence, Social Support, and Self Esteem of Women Victims
}

\author{
Atin Sumiarti* \\ Department of Family and Consumer \\ Sciences, \\ Faculty of Human Ecology, \\ Bogor Agricultural University \\ *Corresponding author: sumiarti.atin@yahoo.com \\ Herien Puspitawati \\ Department of Family and Consumer \\ Sciences, \\ Faculty of Human Ecology, \\ Bogor Agricultural University
}

\begin{abstract}
Domestic violence is action commit by a person to harm a family member. This study aimed to analyze the relationship between domestic violence, social support with self esteem of women as a victims. The sampel were 31 women victims of domestic violence in Bogor, West Java. Sampels were selected by purposive sampling, considering that the sampel had experienced domestic violence by her husband. The result showed that there was a negative correlation between age sampel with domestic violence. In addition, the results found showed a significant positive relationship between the length of education with social support and there is also a significant positive relationship between domestic violence with self esteem of this wife.
\end{abstract}

Keywords: Domestic violence, self esteem, social support, women victim

\begin{abstract}
Abstrak
Kekerasan dalam rumah tangga merupakan suatu tindakan yang dilakukan oleh seseorang yang dapat merugikan salah satu anggota keluarga. Penelitian ini bertujuan untuk menganalisis hubungan kekerasan dalam rumah tangga, dukungan sosial self esteem istri. Penelitian dilakukan terhadap 31 perempuan korban kekerasan dalam rumah tangga (KDRT) di Kota Bogor, Jawa Barat. Teknik pengambilan contoh dilakukan secara purposive dengan mempertimbangkan bahwa contoh pernah mengalami kekerasan dalam rumah tangga yang dilakukan oleh suaminya. Hasil penelitian menunjukkan bahwa ada hubungan negatif antara usia contoh dengan kekerasan dalam rumah tangga. Selain itu, ditemukan hasil yang menyatakan hubungan positif signifikan antara lama pendidikan contoh dengan dukungan sosial dan terdapat juga hubungan positif antara kekerasan dalam rumah tangga dengan self esteem istri.
\end{abstract}

Keywords: dukungan sosial, kekerasan dalam rumah tangga, perempuan korban kekerasan, self esteem 


\section{INTRODUCTION}

Domestic violence is an act that harms one of family member. According to Law Number 23 Year 2004 on the Elimination of Domestic Violence, Article 1 states the following definition, domestic violence is any act against a person, especially a woman resulting in physical, sexual, psychological misery or suffering, or neglect of a household including threats to commit an unlawful act, coercion, or deprivation of liberty in a domestic environment. The consequences of violent acts that occur will leave a deep trauma for the victims.

Social support from formal sources comes from legal institutions that handle cases of violence, health experts, and psychology. Meanwhile, social support from informal sources that comes from large families, friends, and neighbors. Women victims of domestic violence committed by their husbands can ask for help to those who are deemed to be trustworthy and able to overcome the fear that it faces

Domestic violence has a profound negative impact on the victim's selfesteem. Many of the negative impacts that damage self-esteem on the behavior of the victim can lead to arrogance, inability to concentrate, depression, anxiety, sleeplessness, changes in appetite patterns, decreased social competence, emotionally disturbed and always remember the events of violence that happened (Tariq 2013). Handrix's study (2004) referred to in Tariq (2013) states that women who have long experienced violence and persist in the relationship, the lower their self-esteem.

In the private sphere, the institution of marriage has not been a safe place for women characterized by high cases of violence against wives. Many women victims of domestic violence seek to escape from the violence they experience through divorce. However, divorce through religious courts, does not question and prosecute criminal aspects of acts of violence committed by the husband. Moreover, the acts of psychic violence, often difficult in the matter of pembukatian in the realm of crime. So that women victims often solve violence with divorce solutions as a way out of the violence of violence in the household.

Data on violence against women in women's national commissions annual report in 2014 comes from case data handled and received, coming from 191 service provider agencies spread across provinces in the Indonesian territory or about $28 \%$ of the total data of 664 service agencies which was sent to the registration form. The number of cases of violence against women in 2014 was spread by 293220 . The majority of the data were obtained from case / case data handled by the Religious Courts, reaching 280710 cases or 96 percent. The remaining 12510 cases or around 4 percent come from 191 service provider partner institutions.

Forms of violence against women include: violence in the domestic sphere and personal relationships with the number of cases $8626(68 \%)$, violence that 
occurred in the community with the number of cases 3860 (29\%), and violence in the state realm is 24 cases (Women's national commisions 2015).

Until now, information on domestic violence has not been widely studied. Most of the research has focused more on the causes of family violence against wives. Research on the impacts of domestic violence that have been done so far is: the attribution of domestic violence, awareness of gender equality, and the strategy of dealing with the problem of women victims of domestic violence (Nurhayati 2005), analysis of the relationship of domestic violence with the quality of marriage and family welfare (Mutiarawarna 2010), domestic violence relations, coping strategies and stress levels of wives (Ayesya 2012).

Nevertheless, there is still room for further investigation of domestic violence, which is linked to issues of social support and self esteem. Therefore, this study aims to determine the relationship between domestic violence, social support, and self esteem of wife.

\section{RESEARCH METHOD}

This research is an umbrella research about domestic violence. This research use cross sectional study design. The location of this study is Bogor City, West Java which was chosen purposively based on the consideration that Bogor City is an area that has high level of violence cases in household in West Java province. The study was conducted from December to June 2016 covering the activities of making research proposals, data retrieval, data processing, data analysis, and reporting of research results.

Samples of research are victims of domestic violence in Bogor City, West Java. Withdrawal of samples using non-probability sampling method with purposive technique, that is method which is done only on the basis of consideration of the researcher who consider the desired elements already exist in the sample member taken, then done by observation and depth interview. A total of 31 samples were taken purposively according to the criteria of women victims of domestic violence.

The type of data used in this research is primary data and secondary data. How to collect primary data by using questionnaires and interviews. The secondary data in the study was obtained from Center for Integrated Women and Children Empowerment (CIWC) Bogor in the form of data and number of cases of domestic violence along with identity of identified victim. The domestic violence questionnaire refers to the contents of Law No. 23 of 2004 with a cronbach value of 0.906 alpha. The social support questionnaire was the modified result of Zimet, Dahlem, Zimet \& Farley (1988) with a cronbach alpha value of 0.608 and the self esteem wife questionnaire variable was modified from Coopersmith (1967) by Ryden (1978) with a cronbach value of 0.68 . 
Domestic violence variable is measured by statements consisting of 4 scales ( $1=$ Never, 2 = Sometimes, $3=$ Rare, $4=$ Often $)$. The next step of the score is summed and made the interval classification so that the three categories are obtained, namely low, medium, and high. Similarly, social support and self esteem variables are measured by statements consisting of 4 scales $(1=$ Strongly disagree, $2=$ Disagree , $3=$ Agree, $4=$ Strongly agree). The statements of each dimension of the variables are summed and converted in index form to obtain a minimum value of 0 and a maximum of 100 .

Data were analyzed using descriptive analysis to see the distribution of individual and family characteristics, domestic violence, social support, and wife self esteem. Other analysis used is the test of validity, reliability test and correlation test. The correlation test is used to see the relationship between family characteristics, domestic violence, social support, and wife self esteem.

\section{Characteristic of the Sample}

\section{RESULT}

The number of samples in this study were 31 people with the most age categories ie early adulthood (54.8\%) ranged from 18 to 40 years (Hurlock 1980). Samples that included in the middle age category in this study were as many as 13 people or 41.9 percent of the number of samples taken. The highest level of education from the samples is high school graduates / equivalent which means the sample has been studied 9 years compulsory education. There are no sample that do not go to school. All samples have gone through education even though 19.4 percent only graduated from elementary school. Nearly half of the samples (48.4\%) work as entrepreneurs. Most of them work as traders to support their families. Some samples work as domestic workers (16.1\%) whose income is below Regional Minimum Allowance of Bogor City. Most of the samples (83.9\%) earned below Regional Minimum Allowance of Bogor City amounted to 3022765 IDR.

\section{Characteristicof the Family}

The results show that the majority of samples (93.5\%) belong to small families with less than four family members. Family category refers to Bureau of National Population and Family Planning (1996), namely (1) small families whose members are less than or equal to four people; (2) medium families whose members are between five and seven; and (3) large families with more than seven family members. The average family size of samples is 3 people.

\section{Domestic Violence}

Domestic violence is an attacking and coercive pattern of behavior, including physical, psychological, sexual, and even economic attacks by adults against their intimate partners (Grant 1991 referred to in Harahap 2011). According to the Law 
on the Elimination of Domestic Violence, physical violence is an act that results in pain, sickness, or severe injury.

Domestic violence in this study was divided into four dimensions, namely physical violence, psychic violence, sexual violence, and economic violence. In the physical hardness dimension, as much as 74.2 percent included low category and 12.9 percent included in high category. In the dimensions of psychological and economic violence it has the highest percentage in the moderate category of 25.8 percent. The sexual violence dimension has the highest percentage in the low category $(93.5 \%)$ because most samples in the field state that they have never experienced sexual violence based on the questions of the instrument prepared by the researcher. However, there are two samples that experienced sexual violence with a 6.5 percentage in the high category. Both of these samples have openness to the researcher to describe the sexual violence she has suffered.

The results showed that the category of domestic violence that occurred in the field is categorized as low. The results show the low category, but the results explain that all examples have experienced domestic violence. Based on Table 1, the distribution of domestic violence is in the low category with the percentage of 71.0 percent, while 25.5 percent are in the medium category and 3.2 percent are in the high category.

Table 1 Distribution of samples based on domestic violence

\begin{tabular}{lcc}
\hline Category & $\mathrm{n}$ & $\%$ \\
\hline Low (0-33.3) & 22 & 71.0 \\
Medium (33.4-66.6) & 8 & 25.8 \\
High (66.7-100) & 1 & 3.2 \\
\hline Total & 31 & 100 \\
Minimun-Maximum & \multicolumn{2}{c}{$3.7-70.4$} \\
Average \pm Stdev & \multicolumn{2}{c}{$24.13 \pm 18.46$} \\
\hline
\end{tabular}

\section{Social Support}

Social support is the support or care that individuals get from the people around them when in unfavorable conditions. Social support can be provided by family, friends, and neighbors. One of the functions of social support is to enhance positive adjustments as well as personal growth and has also been shown to be a potential buffer against the negative consequences of stress (Sarason et al. 1983 in Naseeh et al., 2012). Social support is also a personal characteristic based on interpersonal relationships (Dichter et al., 2012). Social support is a form of behavior that can foster a sense of comfort and make the individual believe that he is respected, loved, and that other people, individuals, groups and the wider community are willing to give attention and security to the individual concerned.

Social support is divided into three dimensions, namely the dimensions of support of special people / significant others, family support, and friend support. 
The results showed that the social support dimension of the family was higher percentage (45.2\%) than the support of the privileged and the support of friends. It shows that families have a strong influence in the social support received by samples of domestic violence.

Table 2 Distribution of samples based on social support

\begin{tabular}{lcc}
\hline Category & $\mathrm{n}$ & $\%$ \\
\hline Low (0-33.3) & 3 & 9.7 \\
Medium (33.4-66.6) & 24 & 85.7 \\
High (66.7-100) & 4 & 90.3 \\
\hline Total & 31 & 100 \\
Minimum-Maximum & \multicolumn{3}{c}{$33.33-75.00$} \\
Average \pm Stdev & \multicolumn{3}{c}{$51.60 \pm 11.60$} \\
\hline
\end{tabular}

Table 2 shows that social support in sample can be categorized as high $(90.3 \%)$, the rest being in medium category $(85.7 \%)$ and low category $(9.7 \%)$. That is, the sample has received social support from various parties after experiencing violence in the household by their partner.

\section{Self Esteem}

Self-esteem is the attitude to evaluate or assess himself as a whole with a habit of viewing himself especially the attitude of refusing or receiving. Coopersmith (1967) referred to in Susanti (2012) explains that self esteem is an evaluation or self-assessment result of the ability it possesses.

Tabel 3 Distribution of samples based on self esteem

\begin{tabular}{lcr}
\hline Category & $\mathrm{n}$ & $\%$ \\
\hline Low (0-33.3) & 2 & 6.5 \\
Medium (33.4-66.6) & 28 & 90.3 \\
High (66.7-100) & 1 & 3.2 \\
\hline Total & 31 & 100 \\
Minimum-Maximum & $30-70$ & \\
Average \pm Stdev & $59.4 \pm 6.72$ & \\
\hline
\end{tabular}

The results of the study as presented in Table 3 show that the self-esteem rate of the sample is included in the medium category with a percentage of 90.3 percent. Only one sample (3.2\%) has a high self-esteem level and two samples has low self esteem.

\section{Relationship between Characteristics, Domestic Violence, Social Support with Self Esteem of Wife}

Table 4 is a Pearson correlation test that shows the characteristics, domestic violence, social support with the wife's self esteem. In Table 4 it can be seen that the age of the sample is negatively related to domestic violence $(\rho=-0.413)$. That means, the older the sample, the violence would be lower. 
In addition to the negative relationship, the results show that there is a significant positive correlation $(\mathrm{p}<0.05)$, which is the length of education with social support. That menas, the higher education of sample, the higher social support will be obtained. In addition, there is a real positive correlation between domestic violence and self esteem $(\rho=0.358)$. That means, the higher domestic violence in the household, the self esteem will be high.

Table 4 Correlation coefficient between all variables $(n=31)$

\begin{tabular}{lrrr}
\hline Variable & Domestic Violence & Social Support & \multicolumn{2}{c}{ Self esteem } \\
\hline Age & $\mathbf{0 . 4 1 3}^{*}$ & -0.002 & 0.111 \\
Length of education & 0.267 & $\mathbf{0 . 4 0 4}^{*}$ & 0.152 \\
Family size & 0.225 & 0.243 & -0.074 \\
Family income & 0.210 & -0.040 & 0.193 \\
Domestic violence & 1 & 0.018 & $\mathbf{0 . 3 5 8 *}$ \\
Social support & & 1 & 0.037 \\
Self esteem & & & 1 \\
\hline Keterangan $*=$ signifikan pada level 0.05 (2-tailed) & & &
\end{tabular}

\section{DISCUSSION}

This study uses a functional structural theory approach through the concept of domestic violence, social support, and self esteem. A structural functional theory approach can be used to analyze the role of family members in order to function well in maintaining the integrity of families and communities (Newman and Grauerholz 2002 referred to in Puspitawati 2013).

The results show that the majority of samples (93.5\%) come from small families whose members are less than or equal to 4 people. The average number of family members of the sample is 3 persons. According to the results in the field, not all samples come from intact families. That means, there are some samples that have divorced with her partner. The sample work is mostly as an entrepreneur whose incomes are mostly under UMR Bogor City for RACs 022765.

The results show that most of the occurrences of domestic violence experienced by samples fall into the low category, namely, the violence experienced is not very frequent, but has been experienced in a given time. Almost all samples often experience psychic violence from their partners. Social support gained by sample as victims of domestic violence is included in the medium category. The social support of samples get is pretty good. The greatest support gained by sample is family support. The sample is more open to his family than the others.

The result of correlation test showed that there was no correlation between domestic violence with social support and also social support with wife self esteem. This is contrary to research conducted by Okhtavia (2014) which explains that the higher the social support provided, the higher self esteem is owned. Other research 
also states that the higher social support, it will increase one's self esteem (Herdiyanto 2014).

When viewed from the results of existing correlation, this study contradicts the research of Handrix (2004) referred to in Tariq (2013) which states that women who have long experienced violence and persist in the relationship, the lower their self-esteem. The self-esteem of the wife who was the victim of domestic violence initially tended to be low. At first they could not refuse what the husband did because he had a high dependence on husbands. However, the circumstances of the wives who become victims of domestic violence no longer live with their husbands or feel dependent on their husbands make them able to rebuild their confidence and can affect their self-esteem (Destiariani 2012). In this study almost all samples have been divorced. That is, the sample has escaped from the relationship he has lived with the perpetrators of violence. This is supported by the opinion of Naseeh et al. (2012) who say that low and high self esteem can depend on the characteristics of the individual and the family itself.

Other studies suggest that self esteem in childhood will be high. Then decreases as a teenager (Robins, Trzesniewski, Tracy, Gosling \& Potter 2002). In early and middle adulthood, self esteem increases and decreases drastically in late adulthood (Agarwal 2012 in Setyarini \& Atamimi 2012). This is in line with research conducted because the average age of the sample included in middle adulthood.

Another result of the correlation test that has been done, there is a significant positive correlation between the length of education sample with social support. This means that the higher the education of sample, the social support obtained will be high. In addition, there is also a negative correlation between sample's age and domestic violence. That is, the higher the age of the example, it will reduce violence in the household. This is in line with Johnston et al. (2011) which states that acts of violence committed by husbands may be motivated by demographic factors consisting of sex, age, race, education, occupation, family problems, family of origin, marital status, length of relationship, and family income.

\section{Conclusion}

\section{CONCLUSION AND SUGGESTION}

Based on the results of the study it can be concluded that the largest percentage of samples are early adulthood (18-40 years old) and families size of sample based on Bureau of National Population and Family Planning (1996) included in the small family category ( $\leq 4$ persons) of 93.5 percent. The average of sample's education is at the junior high school level. Most of the sample's job is entrepreneur with average income below Regional Minimum Allowance in Bogor City, which is 3022765 IDR as much as 83.9 percent. Domestic violence occurring 
in the field is included in the low category. Social support is classified as medium category. That is, the social support of the sample obtained is quite high. Self esteem of samples included in medium category, which means every individu $\mathrm{h}$ as a fairly good self-esteem despite experiencing events that are less profitable in the life of the household.

From the correlation test results, the correlation variable associated with domestic violence is the age of the sample. Other characteristics are not related to domestic violence. Correlation test results also indicate that domestic violence is positively correlated with wife self esteem. Not only that, also found the result of other characteristics that is the length of sample education related to social support.

\section{Suggestion}

Women and child protection institutions so far not been widely recognized by the wider community. The authors suggest that the institution should more often socialize to the community so that they are aware of the existence of the institution. In addition, the agency should explain that domestic violence is not just physical violence or domestic violence. Beyond that, there are other forms of violence that are also important to the public, such as verbal violence and emotional violence. The community is not afraid to report the violence committed by husbands to women and children protection institutions, so that women and children are protected from the dangers of violence perpetrated by their husbands / fathers. For researchers who interested in researching domestic violence, it is advisable to go deeper into the characteristics of the respondent and to continue with the influence test (regression).

\section{REFERENCES}

[BNPFP]. Bureau of National Population and Family Planning. (1996). National Family Planning Program Policy Board. Jakarta (ID): NPFP.

[NCW]. National Commission for Women. (2015). Annual Report of National Commission for Women. [Internet]. [downloaded January 10, 2016]. Available at: http //: www.komnasperempuan.or.id/catatan-tahunan-komnasperempuan/.

Anderson, K.M., Renner, L.M., \& Danis FS. (2012). Recovery: Resilience and Growth in the Aftermath of Domestic Violence. Violence Against Women, 18 (11), 1279-1299. doi: 10.1177 / 1077801212470543.

Ayesya, Y. (2012). Relationship of Domestic Violence (KDRT), Strategy Coping, and Level of Wife Stress. (Underthesis). Bogor, Indonesia: Faculty of Human Ecology, Bogor Agricultural University.

Davis, T.B., Ullman, S., Tsong, Y., Anderson, G., Counts, P., Tillman, S., Bhang, C., \& Gray, A. (2015). Healing Pathways: Longitudinal Effects of Religious 
Coping and Social Support on PTSD Symtoms in African American Sexual Assault Survivors. Journal of Trauma \& Dissociatio, 16: 114-128. doi: 10.1080 / 15299732.2014.969468.

Destiariani, A.A. (2012). self esteem picture on the wife who become victims of domestic violence. [Undergraduate thesis]. Jakarta, Indonesia: Faculty of Psychology, University of Mercu Buana.

Dichter, M.E., \& Gelles, R.J. (2012). Women's Perceptions of Safety and Risk Following Police Intervention for Intimate Partner Violence. Violence Againts Women. 18(1):44-63.doi:10.1177/10778801212437016.

Helgeson, V.(2012). Psychology of Gender. New York (US): Pearson.

Johnston, P., Minzi, M.L., Hasselt, V.B., Vanderbeek, A., (2011). Domestic Violence and Social Support in a Clinical Sampel of Deaf and Hard of Hearing Women. Journal of Family Violence, 26:63-69. doi:10.1007/s10896010-9342-4.

Mruk, C.J.J., (2006). Self-Esteem Research, Theory, and Practice: Toward a Positive Psychology of Self-Esteem, Third Edition. New York: Springer Publishing Company.

Mutiarawarna, M. (2010). Analysis of Domestic Violence Relations (KDRT) with Quality of Marriage and Family Welfare. [Underthesis]. Bogor, Indonesia: Faculty of Human Ecology, Bogor Agricultural University.

Nasseh, M., Abadi, L., Ghazinour, M., Nojomi, M., Richter, J., (2012). The Buffering Effect of Social Support between Domestic Violence and SelfEsteem in Pregnant Women in Tehran, Iran. Journal of Family Violence. 27:225-231.doi:10.1007/s10896-012-9420-x.

Nurhayati, S.R., (2005). attribution of domestic violence, awareness of gender equality, and problem-facing strategies at women who becomevictims of domestic violence. Journal of Psychology Universitas Gadjah Mada.32 (1).

Okhtavia, S. (2014). Relationship between Family Social Support on Self-Esteem Levels in Post-Stroke Patients. Journal of Psychology of Education and Development. 3 (2): 110-118.

Poerwandari, K., Lianawati, E., (2010). Pocket Handbook for Law Enforcement, Psychic Violence Instruction Guide for Follow-up on Special Report on Domestic Violence. Depok: Women Studies Program, Postgraduate Program University of Indonesia (ID).

Puspitawati, H., (2012). Gender and Family: Concepts and Reality in Indonesia. Bogor, Indonesia: IPB Press.

Robins, R.W., Trzesniewski, K.H., Tracy, J.L., Gosling, S.D., Potter, J.. (2002). Global Self Esteem Across the Life Span. Journal of Psychology and Aging. 17(3):423-434.doi:10.1037//0882-7974.17.3.423. 
Salami, S.O., (2010). Moderating Effects of Resilience, Self-Esteem and Social Support on Adolescents' Reations to Violence. Asian Social Science. 6(12):101-110.

Setyarini, R., Atamimi, N., (2012). self esteem and meaning of life on retired civil servants. Journal of Psychology. 38 (2): 176-184.

Susanti., (2012). Relationship self-esteem and psychological well-being in single women in the field of work. Students Scientific Journal of University of Surabaya. 1 (1): 1-8.

Sutrsiminah, E. (2004). Impact of Violence on Wives In Households On Reproductive Health. Institute of Health Science Ngudi Waluyo, Ungaran.

Tariq, Q. (2013). Impact of Intimate Partner Violence on Self-Esteem of Women in Pakistan. American Journal of Humanities an Social Sciences. 1(1):2530.doi:10.11634/232907811301271.

Turner, H.A., Shattuck, A., Finkelhor, D., Hamby, S. (2015). Effects of PolyVictimization on Adolescent Social Support, Self-Concept, and Psychological Distress. Journal of Interpersonal Violence. 125.doi:10.1177/0886260515586376. 